\title{
Author Correction: Cell segmentation-free inference of cell types from in situ transcriptomics data
}

\author{
Jeongbin Park, Wonyl Choi, Sebastian Tiesmeyer, Brian Long (1D, Lars E. Borm, Emma Garren, \\ Thuc Nghi Nguyen (1D, Bosiljka Tasic (D), Simone Codeluppi (1), Tobias Graf, Matthias Schlesner (D), Oliver Stegle, \\ Roland Eils (i) \& Naveed Ishaque (1)
}

Correction to: Nature Communications https://doi.org/10.1038/s41467-021-23807-4, published online 10 June 2021.

The original version of this Article omitted Wonyl Choi as an equally contributing author and Roland Eils and Naveed Ishaque as cosupervising authors. This has now been corrected in both the HTML and PDF versions of the Article.

Published online: 28 June 2021

(c) (i) Open Access This article is licensed under a Creative Commons Attribution 4.0 International License, which permits use, sharing, adaptation, distribution and reproduction in any medium or format, as long as you give appropriate credit to the original author(s) and the source, provide a link to the Creative Commons license, and indicate if changes were made. The images or other third party material in this article are included in the article's Creative Commons license, unless indicated otherwise in a credit line to the material. If material is not included in the article's Creative Commons license and your intended use is not permitted by statutory regulation or exceeds the permitted use, you will need to obtain permission directly from the copyright holder. To view a copy of this license, visit http://creativecommons.org/licenses/by/4.0/.

(c) The Author(s) 2021 